\title{
Credit risk and loan default among Ghanaian banks: An exploratory study
}

\author{
Matthew Ntow-Gyamfi* and Sarah Serwaa Boateng
}

Department of Finance, University of Ghana Business School, P. O. Box LG 78, Legon, Accra, Ghana

\begin{tabular}{l}
\hline C H R O N I C L E \\
\hline Article history: \\
Received October 16, 2012 \\
Received in revised format \\
27 December 2012 \\
Accepted 12 January 2013 \\
Available online \\
January 152013 \\
\hline Keywords: \\
Credit Risk \\
Loan Default \\
CAMPARI \\
Bank \\
Ghana
\end{tabular}

\section{A B S T R A C T}

\begin{abstract}
Banks are principally in the interest earning business. The interest earning nature of banks comes with the amount of loans that banks are able to advance to their customers. To ensure that the stream of interest is not treacherous, banks must put in place stringent credit risk management practices. In this study, we investigate credit risk and default among Ghanaian banks and how these banks are coping with such pressures. Using a survey method, we found that though varied in nature, all the banks have some form of credit management procedures put in place to manage their loan portfolios. We found loan application processes to be bank specific. However, there are some common requirements that banks usually demand from customers in the process of assessing their suitability for a loan. We also found most of the credit management practices of banks to be consistent with the CAMPARI model. We recommend that the Central Bank facilitate the establishment of a vibrant credit-referencing bureau in order to provide credit history of customers of the banks.
\end{abstract}

\section{Introduction}

The enormous contribution of financial institutions to the development of the economies of countries cannot be overlooked. According to Ntow- Gyamfi and Laryea (2012), financial institutions such as banks although important to every economy are very crucial in the case of developing countries. In the view of Shanmugan and Bourke (1990), the role of banks can be compared with blood arteries in the human body. This is because financial institutions just as blood arteries also pump financial resources (this time not blood) for economic growth from the depositories to where they are required. Banks play an even more critical role in the case of emerging economies where there exists limited borrower access to capital markets (Greuning \& Bratanovic, 2003). In a study by Barth et al. (2004), they provide evidence in support of the fact that a well-functioning commercial banking system accelerates economic growth, while the opposite impedes economic progress and exacerbates poverty.

*Corresponding author. Tel.: +233 543910126

E-mail addresses: matthewntowg@gmail.com (M. Ntow-Gyamfi) 
Notwithstanding the enormous contribution of banks to the development of the economy, they face various risks that can be categorized into three groups; financial risk which has credit risk as part of its components; operational and strategic risk (Cornett \& Saunders, 1999). According to Chijoriga (1997), the magnitude and the level of loss caused by credit risk is severe and is a likely cause of bank failures. Diverse studies have also identified several factors behind bank problems (BrownBridge \& Harvey, 1998; Basel, 1999, Basel, 2004). What appear to be running through the various reasons that these studies provide is the issues of credit problems. This is so partly because of the fact that lending is the main business of commercial banks and issues of default will inevitably occur. For some of these studies, weakness in credit risk management, have been identified to be a prominent cause of banking difficulties.

To help solve this problem, several risk-adjusted performance measures have been proposed (Heffernan, 1996; Kealhofer, 2003). A careful review of the literature reveals that most of the proposed techniques are focused on risk-return trade-off. Banks assess the risk at the particular time customers apply for the loan and interest is charged accordingly. Little has been done on the methods that banks can employ to ensure that loans given out are recovered. That notwithstanding, banks in Ghana have employed their own means of reducing the credit risk that is associated with their lending activities. The gap in literature is that, these bank specific measures may or may not be yielding results but little has been done to assess the practices of banks in relation to credit risk management and loan defaults to see the efficacy of such measures.

Again, in this process of lending, customers of banks complain about the many requirements as well as high rates quoted by the banks. The banks on the other hand are complaining about the high incidence of credit default among the customers and the need to put in place strict measures; hence higher rates to compensate for lost funds through default. It is against this backdrop that this study seeks to assess the credit risk management practices of the banks in Ghana and their associated loan defaults. It is worthy to state that this study helps to provide answers to questions such as; (1) are the credit risk management measures put in place by the banks necessary at all? (2) are these measures helping to curb loan default in the commercial banks? This study investigates the credit risk practices of commercial banks, the level of loan default among banks and finds out the causes of nonperforming loans in bank portfolios.

\section{Literature Review}

Tshorhe et al. (2011) define credit risk as the probability that some of a bank's assets, especially its loans, will decline in value and possibly become worthless. In the banking industry, loans make up a large proportion of firm assets. In most cases, banks' portfolios are relatively illiquid and exhibit the highest credit risk (Koch \& MacDonald, 2000). The management of credit risk is important to banks for the reason that banks usually hold little of equity relative to their asset base and that a small percentage of gross loans going bad can push a bank to the verge of failure. Thus, management of credit risk is very important and central to the health of a bank and indeed the entire financial system (Tshorhe et al., 2011). In order to mitigate credit risk, banks employ the use of an array of techniques. These include but are not limited to collateral guarantees, netting off of loans against deposits of the same counter-party, credit insurance, factoring, debt collection, surety bonds, and letters of credit. Stutz (1985) admits that the use of these techniques may be successful in mitigating the credit risk of a bank but is quick in adding that these techniques also elicit some other types of risk citing legal, operational, liquidity and market risks. According to GTZ (2000) the increased emphasis on risk management reflects a fundamental shift among regulators and bank managers to better anticipate risks rather than just react to them. This new shift places more importance on "self-supervision" and a proactive approach by board members and managing directors to managing their financial institutions (GTZ, 2000). Santomero (1997) and Basel (1999) posit that it is essential for commercial banks to have an effective credit risk management system in place in order to minimize loan losses and so as 
to minimize the credit risk. Best (2001) argued that the purpose of risk management is to prevent an institution from suffering unacceptable losses. In his opinion, an unacceptable loss is any form of loss that causes an institution to fail or materially damages the institution's corporate position. As a result, banks must monitor the ever changing micro and macroeconomic environment to identify the risks they are exposed to and find ways of managing these risks.

To better manage credit risk, management must set up a credit administration team to ensure that once credit is granted it is properly maintained and administered. For Aduda and Gitonga (2011), procedures for measuring a firms overall exposure to credit risk as well as stringent internal rating systems should be adequate and that companies that do not currently have independent risk management structures should set up units that will concentrate fully on the risk management function. Hamzawi (2000) also noted that good risk management necessitates the commitment of banks to certain principles. He explained these principles as: (1) each bank should have an independent risk management committee, which should concern itself with policy preparation, policy implementation and policy monitoring and risk measurement on a regular basis. (2) Banks should classify the various risks and assign the types of risks that fall into that class, develop a specific measure to control the risk in each bank and determine a limit of credit and liquidity. (3) An assessment of the assets and investments of each bank as a basic principle of risk and measurement of profitability should also be undertaken by the bank. (4) The banks must also use modern information systems for risk management and security controls as deemed fit by the independent internal audit committee, which should review the bank's entire business, including risk management.

\section{Methodology}

The study adopts a purposive sampling approach since most of the data needed are those that can only be provided by a particular group of people. Also it is practically impossible to get all the loan officers of all banks in Ghana to complete questionnaires, hence the sample size is only limited to 50 out of the total population. These fifty respondents were selected stochastically from the various banks with branches in Accra. To ensure that the data is representative, not more than five respondents were selected from the same bank. The study uses only primary data in the achievement of its objectives. Questionnaires were designed and pre-tested in order to correct mistakes in the questionnaire. Responses were analyzed using both quantitative and qualitative techniques.

\section{Data Analysis and Discussion of Findings}

\subsection{Gender of Respondents}

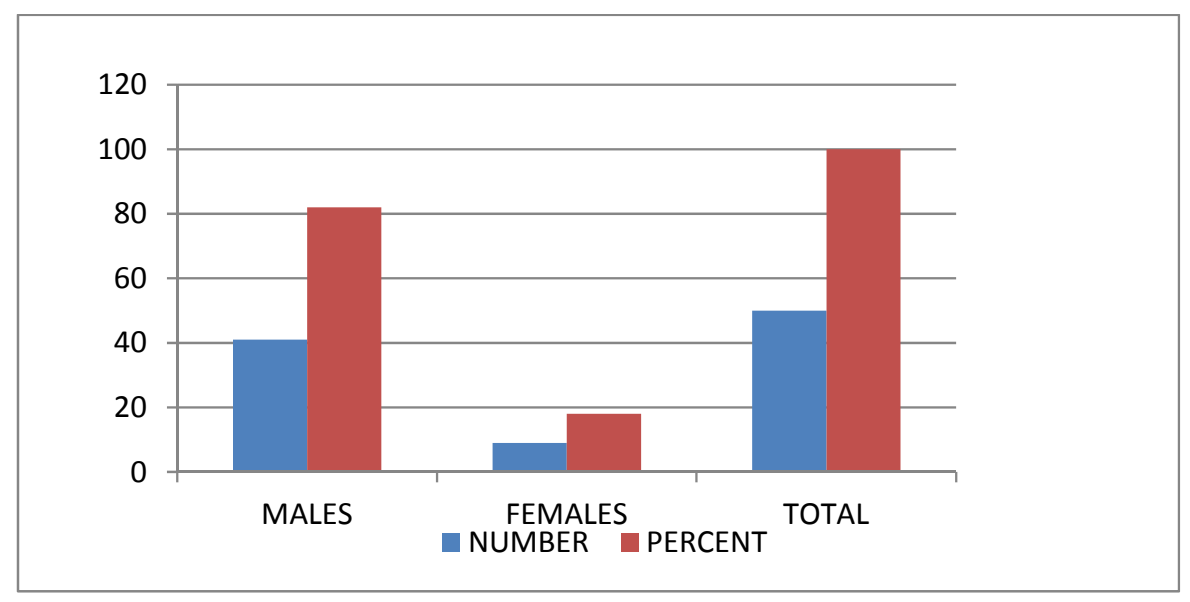

Fig. 1. Gender of respondents 
The responses distributed in the Fig. 1 shows the percentage of males as against females who were part of the sample of the study. It must be stated that the number of the males as against that of females was not determined a priori. However, we find majority of the credit officers of the commercial banks in Ghana being males with just a few of them being females. From Fig. 1, it is clear that majority of the respondents representing about $82 \%$ were males as against their female counterparts who just aggregated about $13 \%$ out of the total sample studied. Although the study's scope is limited, we find the biased nature of the ratio interesting and can only speculate that there might be some peculiar reason why banks do not actually have any policy on who should be a credit officer but an overwhelming majority is found to be males. Further studies may try and investigate into this finding and probably explain why.

\subsection{Number Years of working with current bank}

In order to ascertain whether respondents selected had worked with their current bank quite some time to be able to provide the position of their banks on the issues of credit and default, the study sought to find out how long respondents had been with their current banks as at the time of the inquiry.

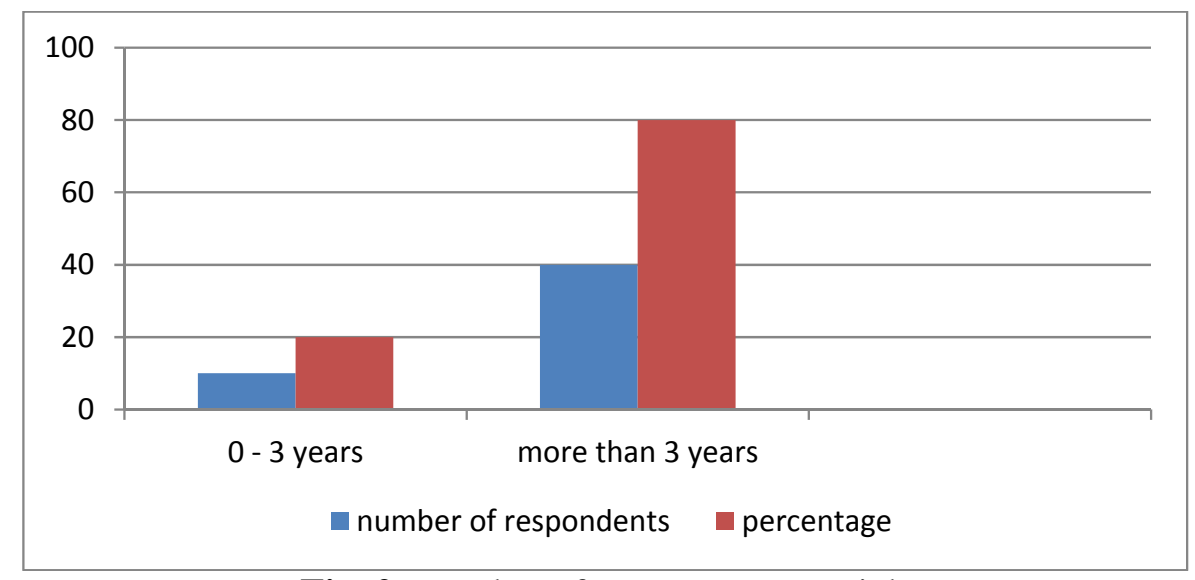

Fig. 2. Number of years on current job

The Fig. 2 above shows the distribution of the number of people and the respective number of years they have been working with their current banks. As stated earlier, this question was to find out whether the responses from these respondents are anything to go by. The study posits that if a particular respondent has been with his current bank for relatively longer period especially as credit or loans officer, that person is in the best position to provide accurate answers as to what the credit risk policies of the bank are and that responses will be shaped by the number of experiences they have found in the course of executing their duties. In Fig. 2 above it is shown that only about $20 \%$ of the total sample gathered were those who had been with their banks for just a few years. The remaining $80 \%$ had been in their current bank for more than 3 years. This shows that the responses are coming from people who truly understand the position of their banks on cases of credit and loans. When asked about their current position with the bank, all the respondents indicated that they were loan or credit officers depending on how the particular bank refers to them. This is however due to the sampling method used. The study sampled using purposive sampling; hence, only credit officers were selected to be part of the study.

\subsection{Target customers}

All the respondents indicated that their banks are in active lending to its numerous customers. As a follow up, the study sought to find the main customers that banks target when it comes to lending. Out of the total number of respondents, $8 \%$ indicated that their banks primarily target micros 
businesses, $4 \%$ primarily target medium scale businesses, another $4 \%$ target large firms, $12 \%$ target individuals, with the remaining $72 \%$ targeting everyone.

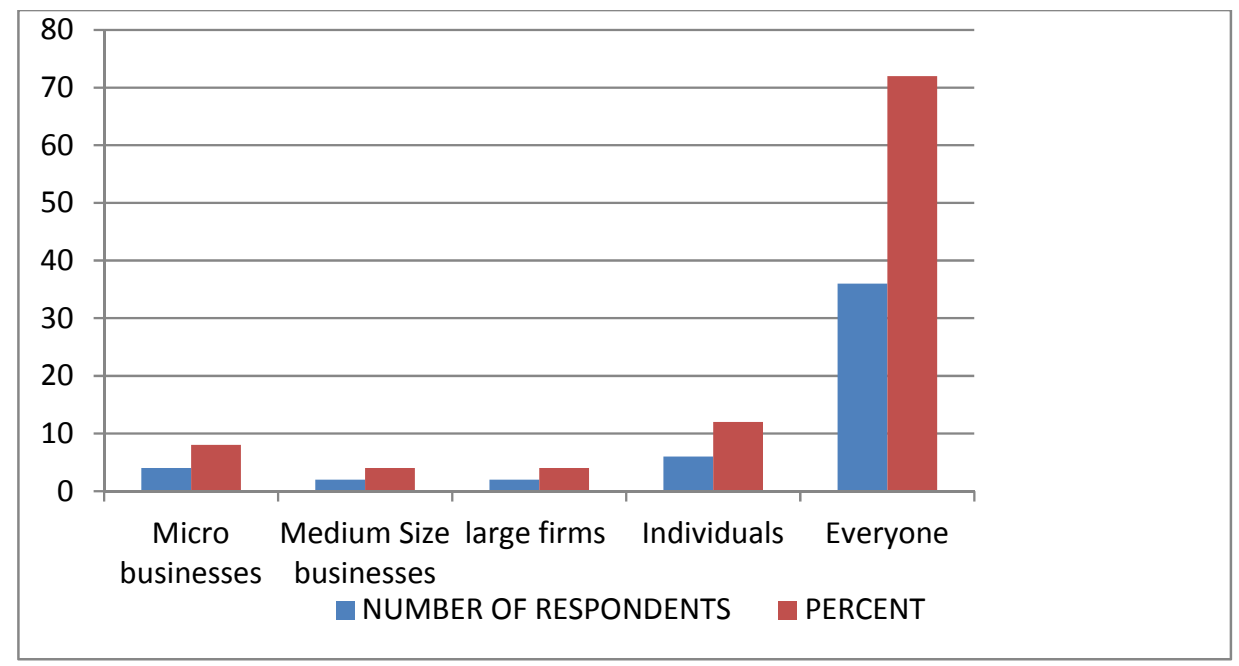

Fig. 3. Target customers

These results show that, the Ghanaian commercial bank does not necessarily target some special people or businesses to provide funds for but are willing and ready to serve all aspects of the market. The results suggest that for these banks, there is nothing like niche marketing when it comes to advancing loans. However, the banks are now cautious in venturing into certain sectors of the economy since such sectors are noted to be characterized by high default rates. Below is a figure to give a snapshot of the situation.

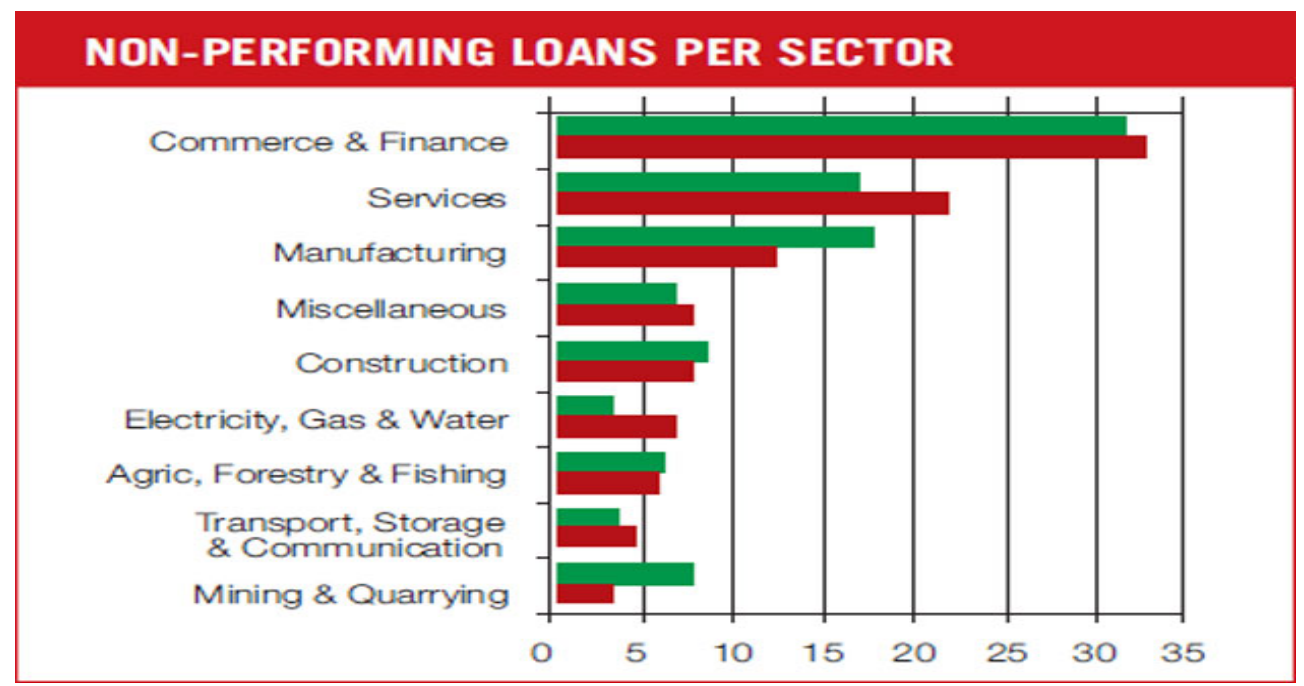

Fig. 4. Non- Performing Loan per Sector (Ref. Central Bank of Ghana)

\subsection{Loan application process}

Although the responses gathered did not show a common line of activities in the loan application processes for all the banks, it was realized that principal line of activities was common for various banks that fall under the scope of the study. In order to warrant a credit facility, one must approach the personal bankers of his/her bank. Sometimes, the banks advertise their readiness for the advancement of credit to its customers. These are accomplished through handbills and posters displayed at the banking hall through the implementation of the text messaging system or sometimes 
adverts at the back of receipts printed from the ATM. In case a customer is a salaried worker whose bankers are those he/she visited, the process begins with the completion of the loan application form. Sometimes these customers are aided to complete the form. The form has to be sent to the credit meeting and since the person is a salaried worker and repayment will be deducted even before the payment of salary, granting such request is not difficult at all. Processing of such loans does not usually go beyond two weeks. For individual customers who are not salaried workers, accessing personal loans from the commercial banks is a little difficult as compared to the customers who may be salaried workers. For businesses, the loan application forms must be accompanied by a detailed business proposal indicating all possible cash flows from the business. The credit department then sends this proposal to credit meetings where various applications are assessed on their own merit. The proposals and cash flow analysis help inform the bank as to which project should be funded or otherwise. When the application is granted at the meeting, the customer is invited over to complete the agreement on the various terms and subsequently the funds are released. Some of the banks even have drafts of loan application letters that they give to the customers to replicate when writing the letter to the bank for the loan. The following are some general requirement by the banks in advancing loans;

i) An operating account with the financial institution and bank statements

ii) Registered business with certificate

iii) Audited financial statements

iv) A guarantor

v) Collateral/ Security

vi) Cash flow projections

vii) Request letter

viii) Personal guarantees

\subsection{Credit Risk Management Systems}

When the respondents were asked about whether or not their banks had credit risk management systems in place to mitigate and manage risk, all the respondents answered yes. Then by making use of the CAMPARI, the study sought to find out how important the various components of CAMPARI means to the bank. The table below shows the distribution of the responses on the CAMPARI among the respondents of the study. The respondents were asked that in granting loans, to what extent does their bank considers the features of the customer in the table.

Table 1

Relative Importance of the CAMPARI model

\begin{tabular}{|c|c|c|c|c|}
\hline & 1 & 2 & 3 & Total \\
\hline $\begin{array}{l}\text { Character; of the borrower in terms of health, integrity, } \\
\text { credit history and commitment to the business }\end{array}$ & $10(20 \%)$ & $17(34 \%)$ & $23(46 \%)$ & $50(100 \%)$ \\
\hline Ability; to manage financial affairs & $12(\mathbf{2 4 \%})$ & $18(36 \%)$ & $20(40 \%)$ & $50(\mathbf{1 0 0 \% )}$ \\
\hline $\begin{array}{l}\text { Mean; having technical, managerial and financial abilities } \\
\text { in order to operate profitably and succeed in business }\end{array}$ & $17(34 \%)$ & $27(54 \%)$ & $6(\mathbf{1 2 \%})$ & $50(\mathbf{1 0 0 \% )}$ \\
\hline Good purpose; for taking the loan & $25(50 \%)$ & $15(30 \%)$ & $10(\mathbf{2 0} \%)$ & $50(\mathbf{1 0 0 \% )}$ \\
\hline $\begin{array}{l}\text { The amount; of the loan should not be excessive given the } \\
\text { size of the business and the equity stake. }\end{array}$ & $38(76 \%)$ & $10(20 \%)$ & $2(4 \%)$ & $50(\mathbf{1 0 0 \% )}$ \\
\hline Show signs of repayments so as to get credit facility & $39(\mathbf{7 8 \%})$ & $9(\mathbf{1 8 \%})$ & $2(4 \%)$ & $50(\mathbf{1 0 0 \% )}$ \\
\hline $\begin{array}{l}\text { Insurance; referred to as security to be provided by the } \\
\text { customer or borrower. }\end{array}$ & $29(58 \%)$ & $11(22 \%)$ & $10(20 \%)$ & $50(100 \%)$ \\
\hline GRAND TOTAL & $170(\mathbf{4 8 . 6 \% )}$ & $107(\mathbf{3 0 . 6 \% )}$ & $73(\mathbf{2 0 . 8} \%)$ & 350 (100\%) \\
\hline
\end{tabular}

Table 1 above shows all the responses gathered by the study in association with the components of the CAMPARI, which are considered and their relative importance when deciding on whether or not to advance loans to customers. On the issues of the character of the owner, only about $20 \%$ of the 
sample highly considers the character of the person taking the loan or the owner of the business that applies for the loan. The study suggest that it may be as a result of the fact that banks concentrate so much on advancing loans to salaried workers and that once they are assured of deducting the regular payment even before the salary is paid out, they cannot be bothered by what the character of the owner may be. This is evident in the fact that a whopping $46 \%$ of the sample responded that character is not really considered when deciding on who gets what.

The story on the ability to manage financial affairs is not all that different from that of the character of the owner. Once again, banks do not look at what ability you have to manage financial matters and that all they want is to be quite sure of their repayment. Only about $24 \%$ highly consider it and 36\% somehow consider it in their analysis. The remaining $40 \%$ do not really consider the ability to manage financial matters as an important factor when advancing loans to their customers.

According to the results of the study, only about $12 \%$ do not really consider having technical, managerial and financial abilities in order to operate profitably and succeed in business as an important factor in deciding who gets how much as loan. The remaining $88 \%$ somehow or highly consider this factor. The study suggests that for the banks that finance projects, they may have to be convinced by the proposal and the statement of cash flow that the project or business is capable of generating cash flows to meet repayment. In the case of a salaried worker, they consider how assured they are that the customer will be able to repay the loan.

Another factor that perhaps is considered by the banks is the purpose for which one is applying for the loan. The results show that $50 \%$ of the respondent's banks highly consider the purpose of the loan. $30 \%$ somehow consider it and $20 \%$ do not really consider that factor in deciding on whether or not to advance loans.

Again, the amount of the loan should not be excessive given the size of the business and the equity stake. This position is loudly proclaimed by the fact that about $76 \%$ of the respondents have their banks highly considering the fact that the amount should not be excessive relative to the size of the business and the percentage of stake the owner has in the business. This shows that banks may want to see that the owner has injected some amount of personal money into the business. This may be a sign of commitment by the owner to the success of the business. Only about $4 \%$ do not really consider this factor.

Perhaps, a sign of repayment is the most important of all the factors that are considered by the banks. This is because it is the factor recording the highest percentage of respondents indicating that their banks highly consider. $78 \%$ of the respondents consider the signs of repayment and would want to see some prelude that the customer will be able to repay the amount. In the data gathering process, one of the respondents stated that banks are even more interested in that than the "health or death of the customer”.

Notwithstanding the above, 58\% of the respondents' banks request some form of security before granting loans. 22\% somehow consider that and the remaining $20 \%$ do not really consider that factor when deciding on the state of a loan application.

Overall, about $48.6 \%$ of the respondents highly consider the various factors in the CAMPARI in deciding on loan applications, 30.6\% somehow consider the CAMPARI and the remaining 20.8\% do not really consider the CAMPARI components in assessing loan applications.

\subsection{Default Level}

The respondents of the study were asked to subjectively rate their default rate for their whole loan portfolio. The responses indicated are shown in the figure 5 below. 


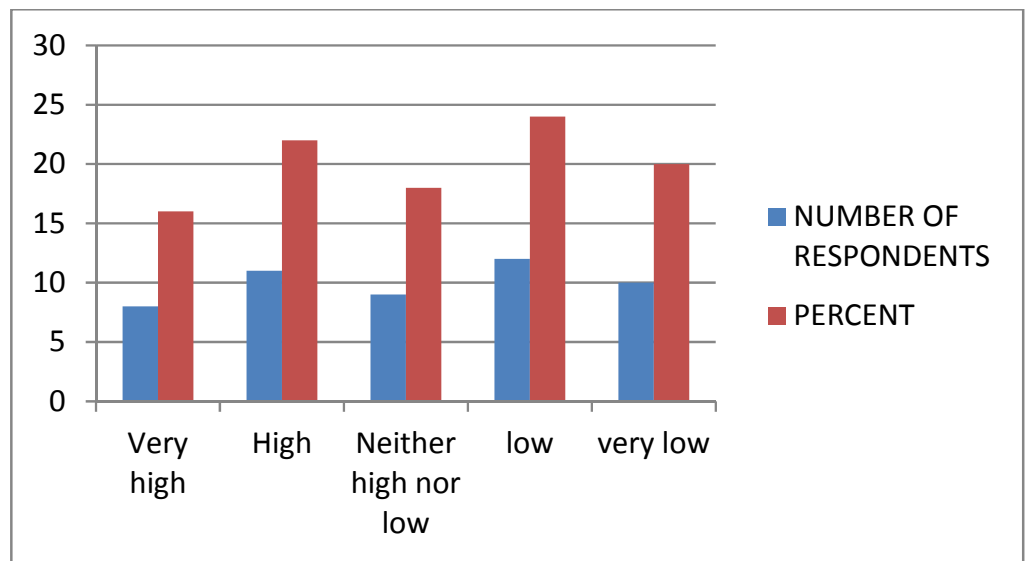

Fig. 5. Default Level

About $16 \%$ of the respondents indicated that their banks have a very high default rate on their whole loan portfolio. 22\% indicated that although their default rates are high there are not very high, $18 \%$ of the respondents said their loan default rate is neither high nor low and that average is what best describe their default rate. $24 \%$ of the respondents stated that their loan defaults are low and that they are on their way to successfully managing loan portfolios. For $20 \%$ of the respondents, very low is the nature of their default rate.

The respondents were then asked about what accounts for default among their customers even though they might have come with nice proposals and good intent. The loan officers gave varying reasons for loan default. For some SMEs request for loans with the brightest of all ideas but the business may not turn out as it was expected. When this happen, cash flows cease and then default subsequently. Some customers simply lack the managerial capabilities to turn the loans they take from the bank into very profitable ventures. Still others, the timing of their projects and that of the loan do not match in that by the time repayment is due, they might not have accumulated enough funds for repayment. Some others also just deliberately refuse to pay with the hedonistic reason that the bank will not be able to trace them. Some also commit themselves to high interest rates especially when they are desperate and later realize that they cannot actually meet the demand.

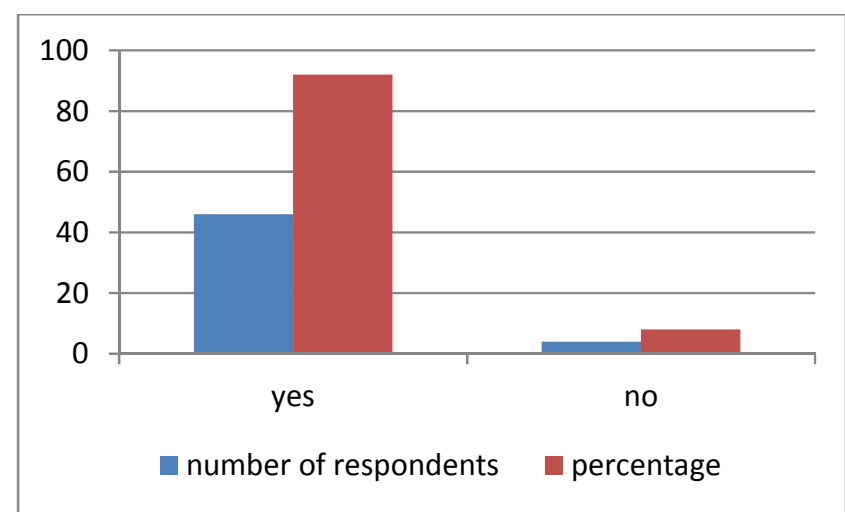

Fig. 6. Risk management and loan default

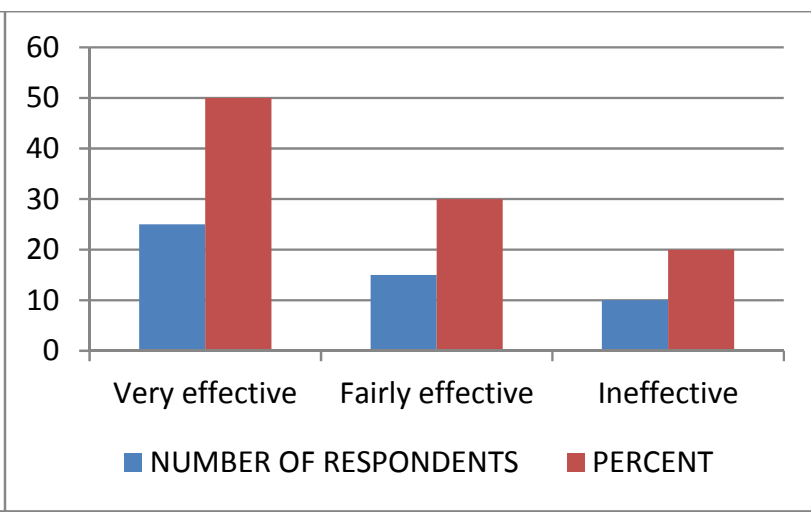

Fig. 7. Credit management ratings

\subsection{Risk management and loan default}

When asked about whether or not there is a relationship between the level of credit risk management and the level of loan default, a 92\% majority affirmed that such a relationship exist by responding yes to the question. Only about $8 \%$ thought the default of loans had nothing to do with the amount of risk management that is done. When asked to describe the relationship, all the respondents who said there 
is a relationship indicated that the lower level of Credit Risk Management the higher the level of default (and vice-versa).

\subsection{Credit management ratings}

The figure above shows the ratings of the respondents of their own banks on the effectiveness of the credit risk management of the bank. 50\% are very effective, $30 \%$ are fairly effective while the remaining $20 \%$ are considered ineffective.

\section{Conclusion}

After a thorough look and evaluation of the situation, the study concludes that commercial banks are using different credit risk management tools to assess and screen their tall list of loan applicants. These tools are designed in such a way that they encompass the tenets of the CAMPARI credit assessment methods. Amidst the usage of all these tools, loan default still remains a canker within the banking sector. Only about $50 \%$ of these tools used by the banks have been found to be very effective. As a result, loan default rate is still at an average rate with a lot to be done in order to keep it very low. Causes of the non-performing loans have been linked to several factors. These include but are not limited to changes in expected cash flow, lack of managerial capacity on the part of the borrowers, mismatch between project cash flow pattern and repayment conditions, and still others deliberate refusal to repay. On a whole, the relationship between credit risk management and loan default rate was found to be negative; meaning as the level of the credit risk management increases in banks, loan default rate reduces. The study concludes that loans defaults are still high and there is more to be done by the banks.

We recommend that banks should tighten their credit assessment procedures. The various components of the CAMPARI should be strictly adhered to by the banks. The Central Bank should facilitate in the establishment of a vibrant credit referencing bureau in order to provide credit history of customers of the banks. This can give the banks an idea of the past record of the loan applicant and his/her likelihood of default so as to put measures in place to avoid it. Banks should also set up business desks where customers can go for advice and education on their business problems. When the businesses of the customers are thriving, then banks can be assured of the repayment of their loans.

\section{References}

Aduda J \& Gitonga J. (2011). The Relationship between Credit Risk Management and Profitability among the Commercial Banks in Kenya. Journal of Modern Accounting and Auditing, 7(9), 934946.

Barth, J. R., Caprio, G. J. \& Levine, R. (2004). Bank regulation and supervision: what works best? Journal of Financial Intermediation, 13, 205-48.

Basel (1999). Principles for the management of credit risk. Consultative paper issued by the Basel Committee on Banking Supervision, Basel.

Basel (2004). Bank failures in mature economies. Working Paper No. 13, Basel Committee on Banking Supervision, Basel.

Best, P. (2001). Stress testing. In Lore, M. \& Borodovsky L. (Eds.). The professional's handbook of financial risk management. Global Association of Risk Professionals (GARP).

BrownBridge, M. \& Harvey, C. (1998), Banking in Africa, James Currey, Oxford.

Chijoriga, M. M. (1997). Application of credit scoring and financial distress prediction models to commercial banks lending: the case of Tanzania, $\mathrm{PhD}$ dissertation, Wirts Chaftsnnversitat Wien (WU), Vienna. 
Cornett, M. M. \& Saunders, A. (1999). Fundamentals of Financial Institutions Management, Irwin/McGraw-Hill, Boston, MA.

Greuning, H. \& Bratanovic, S. B. (2003). Analyzing and Managing Banking Risk: A Framework for Assessing Corporate Governance and Financial Risk, 2nd ed. The World Bank, Washington, DC.

Deutsche Gesellschaft für Technische Zusammenarbeit (2000). A Risk Management Framework for Microfinance Institutions. GmbH Postfach 5180, 65726 Eschborn.

Hamzawi, M. K. K. (2000). Economics of bank credit. Second edition, Munshat Alamrif, Alexandria. Heffernan, S. (1996). Modern Banking in Theory and Practice, Wiley, New York, NY.

Kealhofer, S. (2003). Quantifying credit risk I: default prediction. Financial Analysts Journal, 59(1), 30-44.

Koch, T. W. \& MacDonald, S. S. (2000). Bank Management. The Dryden Press/Harcourt College Publishers, Hinsdale, IL/Orlando, FL.

Ntow - Gyamfi M. \& Laryea A. E. (2012). A Financial Performance Comparison of Foreign VS Local Banks in Ghana. International Journal of Business and Social Science, 3(21).

Santomero, A. M. (1997). Commercial Bank Risk Management: An Analysis of the Process. Wharton School of the University of Pennsylvania, Philadelphia, PA.

Shanmugan, B. \& Bourke, P. (1990). The Management of Financial Institutions: Selected Readings. Addison-Wesley Publishing, Reading, MA.

Tshorhe, J. S., Aboagye A.Q.Q., \& Coleman A. K. (2011). Corporate governance and bank risk management in Ghana. 